This item was submitted to Loughborough's Research Repository by the author.

Items in Figshare are protected by copyright, with all rights reserved, unless otherwise indicated.

\title{
Synthesis and photophysical properties of novel butterfly-shaped blue emitters based on pyrene
}

\section{PLEASE CITE THE PUBLISHED VERSION}

http://dx.doi.org/10.1039/c3ob41350k

\section{PUBLISHER}

(c) Royal Society of Chemistry

\section{VERSION}

AM (Accepted Manuscript)

\section{PUBLISHER STATEMENT}

This work is made available according to the conditions of the Creative Commons Attribution-NonCommercialNoDerivatives 4.0 International (CC BY-NC-ND 4.0) licence. Full details of this licence are available at: https://creativecommons.org/licenses/by-nc-nd/4.0/

\section{LICENCE}

CC BY-NC-ND 4.0

\section{REPOSITORY RECORD}

Feng, Xing, Jian-Yong Hu, Hirotsugu Tomiyasu, Nobuyuki Seto, Carl Redshaw, Mark R.J. Elsegood, and Takehiko Yamato. 2019. "Synthesis and Photophysical Properties of Novel Butterfly-shaped Blue Emitters Based on Pyrene”. figshare. https://hdl.handle.net/2134/18277. 


\title{
Synthesis and photophysical properties of novel butterfly-shaped blue emitters based on pyrene
}

\author{
Xing Feng, ${ }^{\mathrm{a}}$ Jian-Yong Hu, ${ }^{\mathrm{a}, \mathrm{b}}$ Hirotsugu Tomiyasu, ${ }^{\mathrm{a}}$ Nobuyuki Seto, ${ }^{\mathrm{a}}$ Carl Redshaw, ${ }^{\mathrm{c}}$ Mark R. J. \\ Elsegood $^{\mathrm{d}}$ and Takehiko Yamato*a
}

\author{
${ }_{5}$ Received (in $\left.X X X, X X X\right)$ Xth $X X X X X X X X X 20 X X$, Accepted Xth $X X X X X X X X X 20 X X$ \\ DOI: $10.1039 / b 000000 x$
}

Using 1,3,5,9-tetrabromo-7-tert-butylpyrene as the bromide precursor, a series of novel butterfly-shaped 1,3,5,9-tetraaryl substituted pyrene derivatives were synthesized by the Suzuki-Miyaura cross-coupling reaction. Their thermal, photophysical, electrochemical and related properties were systematically

10 investigated. All compounds were found to exhibit high thermal stabilities with decomposition temperatures $\left(T_{\mathrm{g}}\right)$ of up to $300{ }^{\circ} \mathrm{C}$. All compounds show highly blue fluorescence emissions in the spectral region of $412-469 \mathrm{~nm}$ in solutions $\left(\Phi_{\mathrm{f}}: 0.45-0.92\right)$ and $410-470 \mathrm{~nm}$ in the solid-state $\left(\Phi_{\mathrm{f}}: 0.48-0.75\right)$. In particular, the compounds $\mathbf{4 e ,}, \mathbf{4 f}$ and $\mathbf{5}$ show much greater red shifts because of the presence of the larger $\pi$-conjugated acceptor groups, which were verified by theoretical calculations. It is noteworthy that these

15 butterfly-shaped pyrenes 4 possess low-lying HOMO levels ranging from -4.76 to $-5.93 \mathrm{eV}$, which make them promising candidates in OLED applications.

\section{Introduction}

The design and synthesis of efficient organic semiconductors based on polycyclic aromatic hydrocarbons (PAHs) has attracted 20 considerable interest, owing to their potential applications in optoelectronic devices, ${ }^{1}$ such as organic light-emitting diodes (OLEDs), organic photovoltaics (OPVs), organic field-effect transistors (OFETs), etc. In the past two decades, significant efforts have been devoted to explore novel electroluminescent

25 (EL) materials with specific optoelectronic properties. ${ }^{1,2}$ To realize full-color OLED displays, the development of efficient and pure red, green and blue emitters is a significant milestone. However, only the red and green materials have been implemented in devices capable of sufficient efficiencies and 30 lifetimes for commercial value, ${ }^{3}$ whilst the availability of blue emitters with satisfactory multifunctional properties for high-performance OLEDs still remains a challenge.

Pyrenes $^{4}$ as classical members of the PAHs have attracted great interests from the scientific community, not only because of their 35 planar structure, but also their excellent fluorescence properties, which has led to their wide utilization as fluorescence probes. Recently, a number of synthetic methods for the synthesis of novel PAHs based on pyrene have been reported, ${ }^{5}$ and their potential uses as chemosensors were exploited. ${ }^{6}$

40 However, the flat structure of pyrene has restricted its use for developing EL materials for OLED applications, primarily because of the tendency towards $\pi$-stacking and excimer formations, which would quench the emission intensity with low fluorescence quantum efficiency. One strategy to suppress the ${ }^{45}$ passive $\pi-\pi$ stacking interactions in condensed medias is to introduce appropriate substituents into the pyrene core. The methods tend to attach substituents at the 1-, 3-, 6- and 8positions of the pyrene so as to affect both the overall photophysical properties and the geometrical structures. For 50 example, 1,3,6,8-tetraphenylpyrene (TPPy) exhibited a pure blue fluorescence with a high quantum yield ( $\Phi_{\mathrm{f}}=0.90$ in cyclohexane). ${ }^{7}$ Bulky aryl groups have been located at the 1,3,6,8-positions for the preparation of tetraaryl-functionalized pyrenes which showed high efficiencies with deep-blue emission, ${ }_{55}$ low turn-on voltages and high brightness in OLED devices. ${ }^{8}$ Sotoyam and co-workers have investigated different phenyl moieties 1,3,6,8-tetrasubstituted pyrene and how they affect the fluorescent properties by molecular orbitals (MOs) methods. ${ }^{9}$ The tert-Butyl groups located at the 2- or the 2- and 7-positions of the 60 pyrene core play an important role in inhibiting the undesirable $\pi$-stacking interactions in the solid-state. Thus, the cruciform-, hand-, and Y-shaped pyrene derivatives were reported and can be potentially used as blue emitters in OLEDs. ${ }^{10}$

Previously, a novel bromide precursor 1,3,5,9-tetrabromo-765 tert-butylpyrene was prepared from 2-tert-butylpyrene and $\mathrm{Br}_{2}$ in $\mathrm{CH}_{2} \mathrm{Cl}_{2}$ in the presence of iron powder (6 equiv.) at room temperature. ${ }^{11}$ Based on this key intermadiate, herein, we access a series of butterfly-shaped compounds of 1,3,5,9-tetraarylpyrenes with deep-blue fluorescence properties. Several 4-substituted 70 phenyl groups were successfully introduced into the pyrene core at the 1,3,5,9-positions. Not only does this category of materials have great potential in organic materials, such as blue emitters for OLED applications, but will also be useful to understand the structure-property relationships of the current butterfly-shaped 75 1,3,5,9-tetraarylpyrenes relative to the other arylpyrenes. 


\section{Results and discussion}

\section{Synthesis}

The synthetic route to the butterfly-shaped pyrene derivatives 4af are illustrated in Scheme 1. By using the 5 1,3,5,9-tetrabromo-7-tert-butylpyrene (2) ${ }^{11}$ as the key intermediate, the compounds of type 4 were synthesized by the Suzuki-Miyaura cross-coupling reaction with the corresponding arylboronic acids (3) in 48-72\% yields. To investigate the effect of a terminal moiety on the structure-property relationships in 10 these butterfly-shaped pyrenes systems, the reaction of $\mathbf{4 f}$ with 17.0 equiv. of hydroxylamine hydrochloride in ethanol solution afforded the corresponding oxime $\mathbf{5}$ in $\mathbf{7 6 \%}$ yield according to the literature approach. ${ }^{12}$ Furthermore, in order to investigate the effect of the tert-butyl group of the pyrene on photophysical 15 properties, $\mathbf{6}$ was synthesized from $\mathbf{4 a}$, in which the bulky steric tert-butyl group has been removed by Nafion-H catalyzing. ${ }^{13}$ The chemical structures of all synthesized compounds were confirmed by their ${ }^{1} \mathrm{H} /{ }^{13} \mathrm{C}$ NMR spectra, FT-IR spectroscopy, mass spectrometry, as well as elemental analysis.
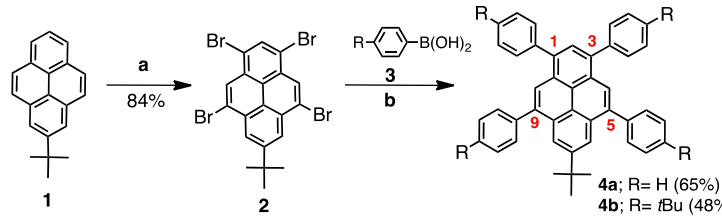
$4 \mathbf{4} ; R=t B u(48 \%)$
$4 c ; R=O M e(65 \%)$$$
\text { (2) }
$$

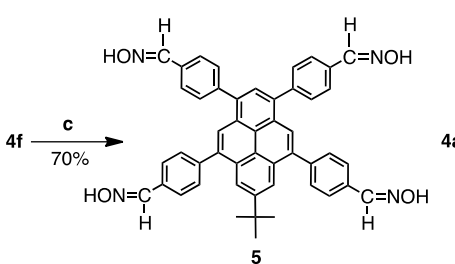
4d; $\mathrm{R}=\mathrm{CF}_{3}(63 \%)$

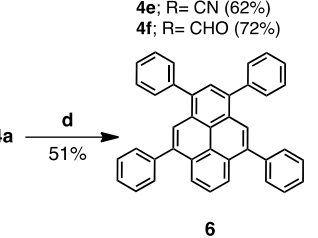

Scheme 1 Synthetic route to the compounds 4, 5 and 6. Reagents and conditions: (a) iron powder, $\mathrm{Br}_{2}, \mathrm{CH}_{2} \mathrm{Cl}_{2}$, room temp., $4 \mathrm{~h}, 84 \%$. (b) $\mathrm{Pd}\left(\mathrm{PPh}_{3}\right)_{4}$, toluene, $\mathrm{K}_{2} \mathrm{CO}_{3}, 90{ }^{\circ} \mathrm{C}, 24 \mathrm{~h}$. (c) $\mathrm{NH}_{2} \mathrm{OH} \cdot \mathrm{HCl}$, ethanol, $\mathrm{NaOH}$, reflux, $12 \mathrm{~h}$. (d) Nafion-H, $o$-xylene, $160^{\circ} \mathrm{C}, 24 \mathrm{~h}$.

\section{${ }_{25}$ Thermal properties}

Thermal stability is an important physical parameter to evaluate EL materials for OLED applications. We investigated the thermal stability of these butterfly-shaped pyrene derivatives $\mathbf{4}$ and $\mathbf{5}$ by thermogravimetric analysis (TGA) and differential scanning 30 calorimetry (DSC) under a nitrogen atmosphere at a heating rate of $10{ }^{\circ} \mathrm{C} \mathrm{min}^{-1}$. The TGA data revealed that the butterfly-shaped compounds 4 showed high thermal stabilities in the range of 250-450 ${ }^{\circ} \mathrm{C}$, with a $5 \%$ weight loss. (Fig. 1), and the following stability order $\mathrm{CN}>\mathrm{OMe}>t-\mathrm{Bu}>\mathrm{H}>\mathrm{CHO}>\mathrm{CF}_{3}>5$. From the

${ }_{35}$ TGA data, the amount of carbonized residue (char yield) of $\mathbf{4 c}, \mathbf{4 e}$, 4f and $\mathbf{5}$ in a nitrogen atmosphere was higher (20\% for $\mathbf{4 c}$, $\mathbf{4 f}$, $37 \%$ for $\mathbf{4 e}$ and $64 \%$ for 5 ) than $\mathbf{4 a}$, $\mathbf{4 b}$ and $\mathbf{4 d}$ with almost complete loss, which means that $\mathbf{4 c}, \mathbf{4 e}, \mathbf{4 f}$ and $\mathbf{5}$ possess more aromatic components than $\mathbf{4 a}, \mathbf{4 b}$ and $\mathbf{4 d}{ }^{14}$ Ascribe from the 40 substituent group [What does this mean? Please re-write.] at para-position of the phenyl would affect the thermal property. No glass transition temperature $\left(T_{\mathrm{g}}\right)$ was observed for any of the compounds.

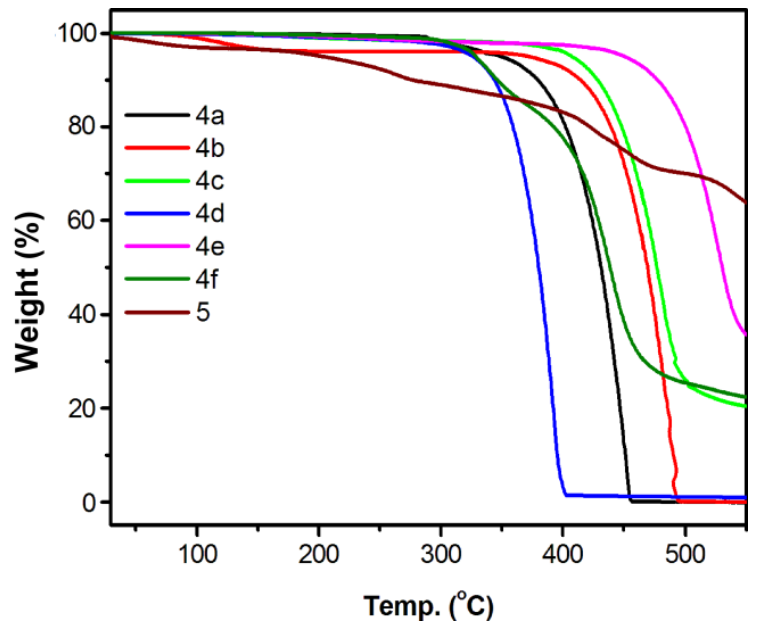

45 Fig. 1 TGA curves of compounds 4 and 5.

\section{Photophysical properties}

We measured the UV-vis absorption and fluorescence (FL) spectra of compounds 4-6 in both dichloromethane solutions $\left(\sim 10^{-5} \mathrm{M}\right)$ and thin films. The key data are summarized in Table 501 .
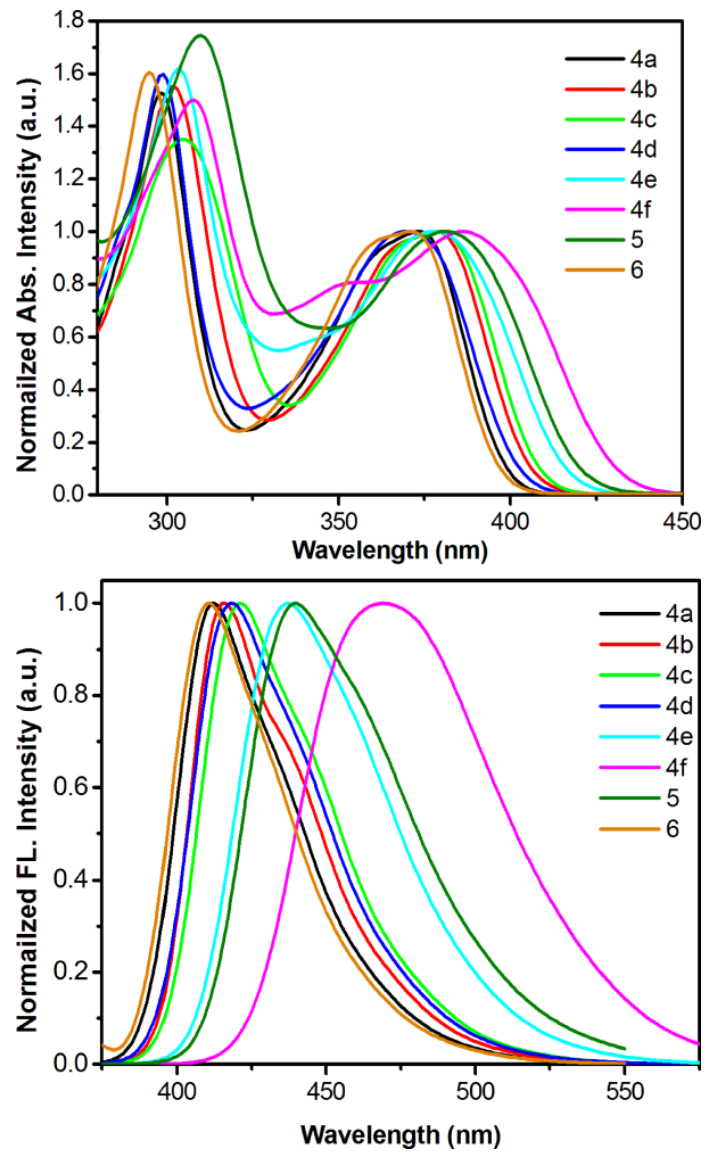

Fig. 2 (a) Normalized UV-vis absorption and (b) fluorescence emission spectra of compounds $\mathbf{4}$ and $\mathbf{5}$ recorded in dichloromethane solutions at $\sim 10^{-5}-10^{-6} \mathrm{M}$ at $25^{\circ} \mathrm{C}$. 
Table 1 The photophysical and electrochemical properties of compounds 4, 5 and 6.

\begin{tabular}{|c|c|c|c|c|c|c|c|c|}
\hline \multirow{2}{*}{$\frac{\text { Compound }}{4 \mathbf{a}}$} & \multicolumn{2}{|c|}{$\underline{\lambda_{\max }} \frac{\text { abs (nm) }}{\text { solns }^{a} / \text { films }^{b}}$} & \multicolumn{2}{|c|}{$\underline{\lambda_{\max }} \frac{\text { PL (nm) }}{\text { solns }^{a} / \text { films }^{b}}$} & \multirow{2}{*}{$\begin{array}{c}\Phi_{f}^{c} \\
\text { solns / thin films } \\
0.92 / 0.75\end{array}$} & \multirow{2}{*}{$\begin{array}{c}\text { Stokes shift }\left(\mathrm{cm}^{-1}\right) \\
\text { solns }^{a} / \text { films }^{b}\end{array}$} & \multirow{2}{*}{$\frac{\tau(\mathrm{ns})}{4.57}$} & \multirow{2}{*}{$\frac{T_{m}{ }^{d} / T_{d}{ }^{e}\left({ }^{\circ} \mathrm{C}\right)}{335 / 350}$} \\
\hline & 373 & 380 & 412 & 410 & & & & \\
\hline $4 b$ & 378 & 379 & 416 & 435 & $0.45 / \mathrm{nd}$ & $38 / 56$ & 5.18 & $332 / 407$ \\
\hline $4 c$ & 379 & 369 & 421 & 443 & $0.90 / 0.72$ & $42 / 74$ & 5.82 & $330 / 410$ \\
\hline 4d & 370 & 358 & 418 & 466 & $0.91 / \mathrm{nd}$ & $48 / 108$ & 12.2 & 258/328 \\
\hline $4 e$ & 378 & 387 & 437 & 460 & 0.89 / nd & $59 / 73$ & 7.51 & $378 / 450$ \\
\hline $4 f$ & 386 & 400 & 469 & 471 & $0.56 / 0.48$ & $83 / 71$ & 4.04 & 302/329 \\
\hline 5 & 381 & nd & 440 & nd & 0.63 / nd & 59 / nd & 4.53 & $214 / 250$ \\
\hline 6 & 371 & nd & 411 & nd & $0.26 / \mathrm{nd}$ & $40 / \mathrm{nd}$ & 5.10 & 244/nd \\
\hline
\end{tabular}

${ }^{a}$ Maximum absorption wavelength measured in dichloromethane at room temperature. ${ }^{b}$ Measured as thin neat films. ${ }^{c}$ Measured in dichloromethane and as neat thin films, respectively. ${ }^{d}$ Melting temperature $\left(T_{\mathrm{m}}\right)$ obtained from differential scanning calorimetry (DSC) measurements. ${ }^{e}$ Decomposition temperature $\left(T_{\mathrm{d}}\right)$ obtained from thermogravimetric analysis (TGA). nd: not determined.
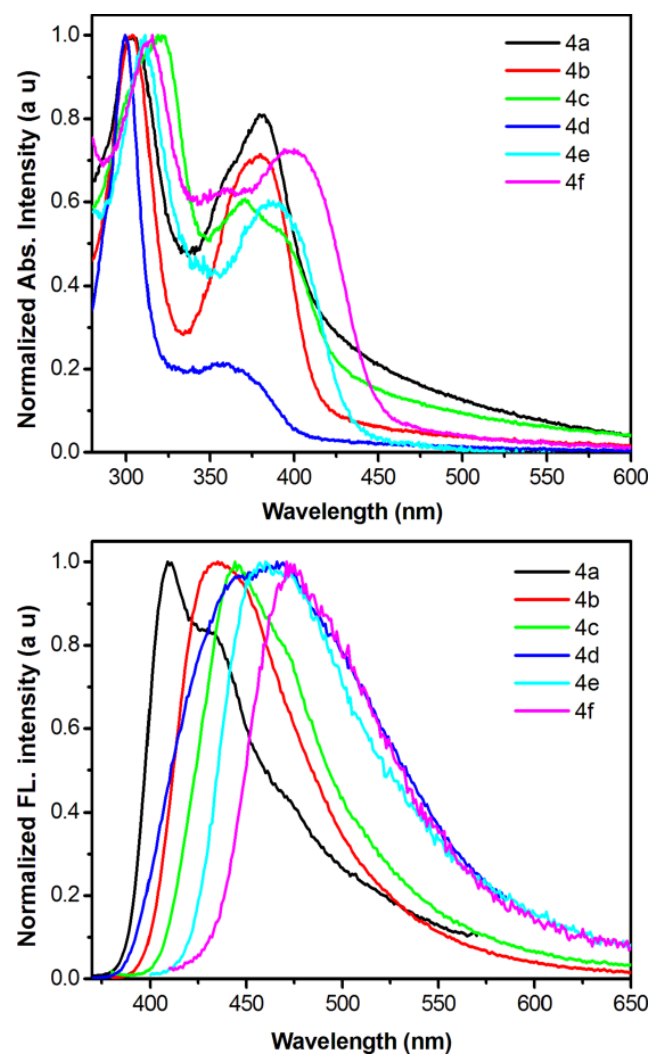

Fig. 3 (a) Normalized UV-vis absorption and (b) emission spectra of $\mathbf{4 a}-\mathbf{f}$ as thin neat films.

Fig. 2 illustrates the normalized absorption and FL spectra of 5 of 4, 5 and $\mathbf{6}$ in dilute dichloromethane solutions. The absorption spectra of these butterfly-shaped pyrene derivatives $\mathbf{4}$ and $\mathbf{6}$ exhibited well-resolved profiles in the range of $280-480 \mathrm{~nm}$. The short wavelength absorption peak located at 277-279 nm and the long wavelength maximum $\left(\lambda_{\max }\right)$ occur at $370-381 \mathrm{~nm}$, assigned 10 to the $\pi-\pi^{*}$ and the $n-\pi^{*}$ transitions (Fig. 2a), respectively. Noticeably, 4f and 5 showed slightly red shifts of $\sim 10 \mathrm{~nm}$ compared to the other compounds due to the effective increase in conjugation length. It is noteworthy that the compound $\mathbf{6}$ exhibited a blue shift $(8 \mathrm{~nm})$ after the removal of the tert-butyl 15 group from the 2-position of the pyrene core compared to $4 \mathbf{c}$, arising from the improved energies of both $S_{1} \leftarrow S_{0}$ excitations and $\mathrm{S}_{2} \leftarrow \mathrm{S}_{0}$ excitations. ${ }^{15}$

Upon excitation at the absorption maximum in $\mathrm{CH}_{2} \mathrm{Cl}_{2}$, all compounds exhibited deep-blue to sky-blue FL with sharp 20 emission maximum peaks at $412 \mathrm{~nm}$ for $\mathbf{4 a}, 416 \mathrm{~nm}$ for $\mathbf{4 b}, 421$ $\mathrm{nm}$ for 4c, $418 \mathrm{~nm}$ for $\mathbf{4 d}, 437 \mathrm{~nm}$ for $\mathbf{4 e}, 440 \mathrm{~nm}$ for $\mathbf{5}$ and $411 \mathrm{~nm}$ for 6 (Fig. 2b). In the case of $\mathbf{4 f}$, which showed a maximum peak at $469 \mathrm{~nm}$, there was a larger Stokes shift of 83 $\mathrm{nm}$ relative to the other butterfly-shaped compounds, suggesting 25 that its electronic structure in the ground state is significantly different from that in the excited state. It is noted that $\mathbf{4 e}$ and $\mathbf{5}$ showed almost the same emission peaks, suggesting that the $\mathrm{C} \equiv \mathrm{N}$ and $-\mathrm{C}=\mathrm{N}-\mathrm{OH}$ groups make similar electronic contibutions. This result implies that changing the terminal group at the so para-position of the phenyl moiety can affect the electron transition absorption, which also agrees with our previous report. ${ }^{10 a}$ Furthermore, a substituent effect involving $S_{1} \leftarrow S_{0}$ was also observed in the emission spectra, and without the tert-butyl group in compound $\mathbf{6}$, the emission maximum displayed a lower ${ }_{35}$ red shift of $\sim 10 \mathrm{~nm}$ compared to the corresponding compound $\mathbf{4 c}$.

We also investigated the photophysical properties of $\mathbf{4}$ in the solid-state. The UV-vis absorption and photoluminescence (PL) spectra data are also listed in Table 1. As shown in Fig. 3, the absorption spectra of these butterfly-shaped pyrenes 4 , possessing

40 similar frameworks (pyrene-based core), exhibited a similar absorption band with a slight red shift $(\sim 14 \mathrm{~nm})$ to those in dilute solutions. Compared with the FL in solutions, the PL spectra of 4a-f and $\mathbf{5}$ in thin films exhibited highly blue emissions with a maximum peak in the range of 410-471 nm, without extra 45 excimer emissions, while compounds $\mathbf{4 b}-\mathbf{e}$ displayed a red-shift ( 48 nm), ascribed to the tert-butyl group located at the 7 -position and the tetraaryl moieties at the 1,3,5,9-positions which can prevent $\pi$-aggregations via the intra/intermolecular interactions in the solid-state. The single-crystal packing revealed 50 that no $\pi-\pi$ stacking was observed, ${ }^{11}$ however, the aggregations cannot be sufficiently suppressed ${ }^{16}$ due to the small blocking group of the arylphenyl located at the 1,3,5,9-positions. Thus, larger red-shifts occurred in $\mathbf{4 c}$ and $\mathbf{4 d}$. Fig. $2 \mathrm{~b}$ and $3 \mathrm{~b}$ revealed that these butterfly-shaped compounds $\mathbf{4}$ and $\mathbf{5}$ emit very bright 55 and sharp blue fluorescence in both solution and the solid-state. The newly developed butterfly-shaped pyrenes $\mathbf{4 a - e}$ and $\mathbf{5}$ have very high quantum yields $\left(\boldsymbol{\Phi}_{\mathrm{f}}\right)$ in the range of $0.89-0.92$ in solutions and $0.72-0.78$ in the solid-state. Due to the presence of 
Table 2 Optical and electrochemical properties of compounds 4, 5 and 6.

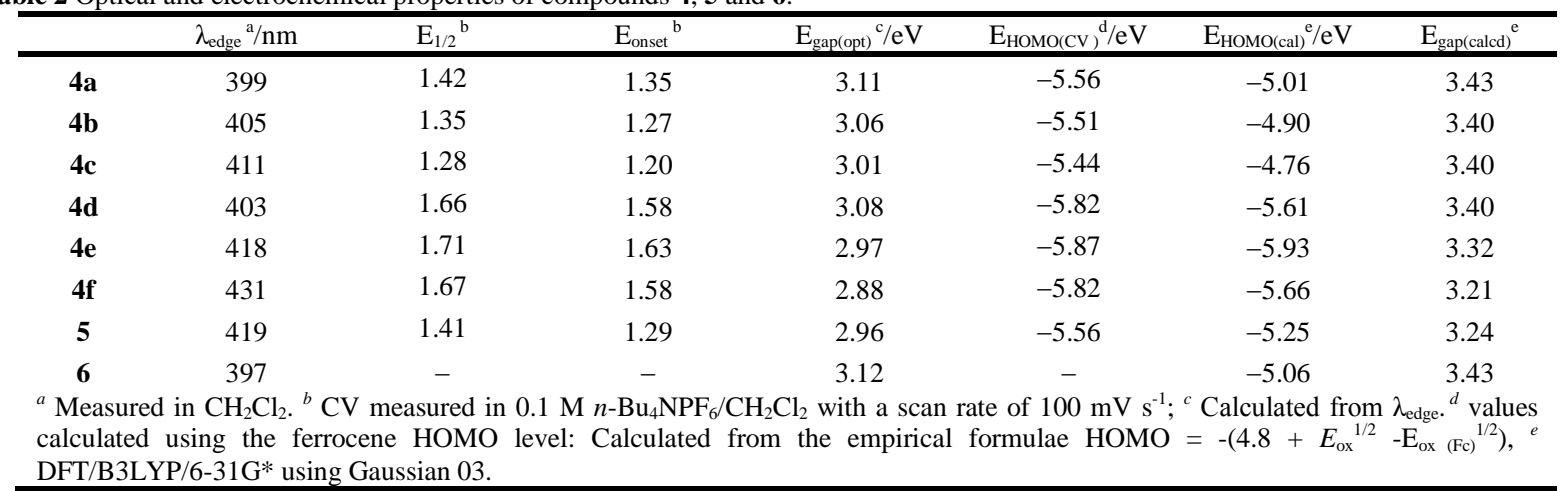

the $-\mathrm{CHO}$ in $\mathbf{4 f}$ that has efficient intramolecular conjugation and increased $\pi-\pi$ intermolecular interactions that would quench the FL with quantum yields of 0.56 in solution and 0.48 in the solid-state. However, 6 exhibited a lower quantum yield of 0.26 5 compared with the TPPy $\left(\Phi_{f}=0.90\right){ }^{7}$ which is probably due to the strong intermolecular interactions without the bulky steric tert-butyl group. Fluorescence lifetimes of 4-6 were determined in dichloromethane solution at $10^{-5} \mathrm{M}$ with $\tau=4.04-12.2 \mathrm{~ns}$.
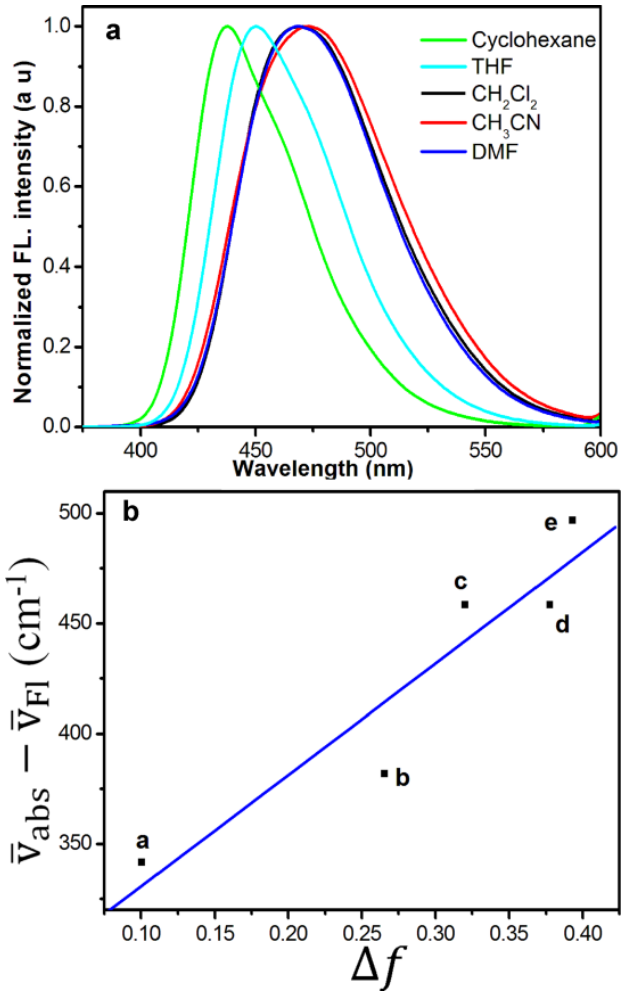

${ }_{10}$ Fig. 4 (a) Emission spectra of $\mathbf{4 f}$ in cyclohexane, THF, $\mathrm{CH}_{2} \mathrm{Cl}_{2}, \mathrm{CH}_{3} \mathrm{CN}$ and DMF at $25^{\circ} \mathrm{C}$. (b) Lippert-Mataga plots for compound $4 \mathrm{c}(\mathrm{CHO})$ : (a) cyclohexane, (b) $\mathrm{CH}_{2} \mathrm{Cl}_{2}$, (c) THF, (d) DMF, (d) $\mathrm{CH}_{3} \mathrm{CN}$.

Concentration-dependent UV-vis absorption and FL spectra studies in $\mathrm{CH}_{2} \mathrm{Cl}_{2}$ confirmed that these compounds did not 15 change with concentration in solution, even on increasing the concentrations from $10^{-6} \mathrm{M}$ to $10^{-3} \mathrm{M}$ (See Supporting
Information). On the other hand, we examined the solvatochromism of $\mathbf{4}$ and $\mathbf{5}$ in various solvents, such as cyclohexane, tetrahydrofuran (THF), $\mathrm{CH}_{2} \mathrm{Cl}_{2}, \mathrm{CH}_{3} \mathrm{CN}$, and $20 \mathrm{~N}, \mathrm{~N}$-dimethylformamide (DMF) (Fig. 4a). In the compounds $\mathbf{4 a}-$ e and 5, the emission maxima were slightly shifted by $\sim 5 \mathrm{~nm}$ depending on the solvent polarity. However, although the absorption spectrum of compound $\mathbf{4 f}$ does not show any change, the solvent dependence in the emission spectra of $\mathbf{4 f}$ is 25 remarkable with large bathochromic shifts of $\sim 36 \mathrm{~nm}$ on going from non-polar solvents (cyclohexane) to polar solvents (DMF). The linear relationship of Stokes shift $\left(\Delta v_{\mathrm{st}}\right)$ against the solvent parameter $\Delta_{\mathrm{f}}(\varepsilon, \mathrm{n})^{17}$ was determined by the Lippert-Mataga plot (Fig. 4b), which evaluated the effect of solvent molecules for day 30 molecules fluorescence by hydrogen bond [This does not make any sense - please re-write]. ${ }^{18}$ This solvatochromism can be attributed to the decrease in the energy of the singlet-excited states as a function of an increase in the polarity of the solvents. ${ }^{19}$

$$
\Delta v=\frac{1}{4 \pi \varepsilon_{0} \mathrm{hca}^{3}} \frac{2 \Delta \mu^{2}}{h \mathrm{cR}^{3}} \Delta f+\text { const }
$$

35 where $\Delta \mathrm{v}=\mathrm{v}_{\mathrm{abs}}-\mathrm{v}_{\mathrm{em}}$ stands for Stokes shift, $\mathrm{v}_{\mathrm{abs}}$ is wavenumber of maximum absorption, $\mathrm{v}_{\mathrm{em}}$ is the wavenumber of maximum emission, $\Delta \mu=\mu_{\mathrm{e}}-\mu_{\mathrm{g}}$ is the difference in the dipole moment of solute molecule between excited $\left(\mu_{\mathrm{e}}\right)$ and ground $\left(\mu_{\mathrm{g}}\right)$ states, $h$ is Planck's constant, $\mathrm{R}$ is is the radius of the solvent cavity in which 40 the fluorophore resides (Onsager cavity radius), and $\Delta \mathrm{f}$ is the orientation polarizability given by (Eq. 2)

$$
\Delta \mathrm{f}=\frac{\varepsilon-1}{2 \varepsilon+1}-\frac{\mathrm{n}^{2}-1}{2 \mathrm{n}^{2}+1}
$$

where $\varepsilon$ is the static dielectric constant and $n$ the refractive index of the solvent.

\section{${ }_{45}$ Electrochemical properties}

We investigated the electrochemical properties of these compounds by cyclic voltammetry (CV) recorded in $\mathrm{CH}_{2} \mathrm{Cl}_{2}$ solution using ferrocene $\left(\mathrm{Fc} / \mathrm{Fc}^{+}\right)$as the internal standard with a scan rate of $100 \mathrm{mVs}^{-1}$ at room temperature. Fig. 5 displays the 50 cyclic voltammograms (CVs) of $\mathbf{4}$ and $\mathbf{5}$. All compounds exhibited quasi-reversible oxidations in $\mathrm{CH}_{2} \mathrm{Cl}_{2}$. Interestingly, the compounds $\mathbf{4 b}$ and $\mathbf{4 c}$, with electron-donating groups, showed two reversible oxidation waves, while the compounds $\mathbf{4 d - f}$ and $\mathbf{5}$, with electron-withdrawing groups, have only one reversible 55 oxidation each. These results differ from the Y-shaped compounds that we recently reported, ${ }^{10 c}$ Obviously, the substituent positions play a significant role in affecting the 


\section{Cite this: DOI: 10.1039/c0xx00000x}

\section{www.rsc.org/xxxxxx}

\section{ARTICLE TYPE}

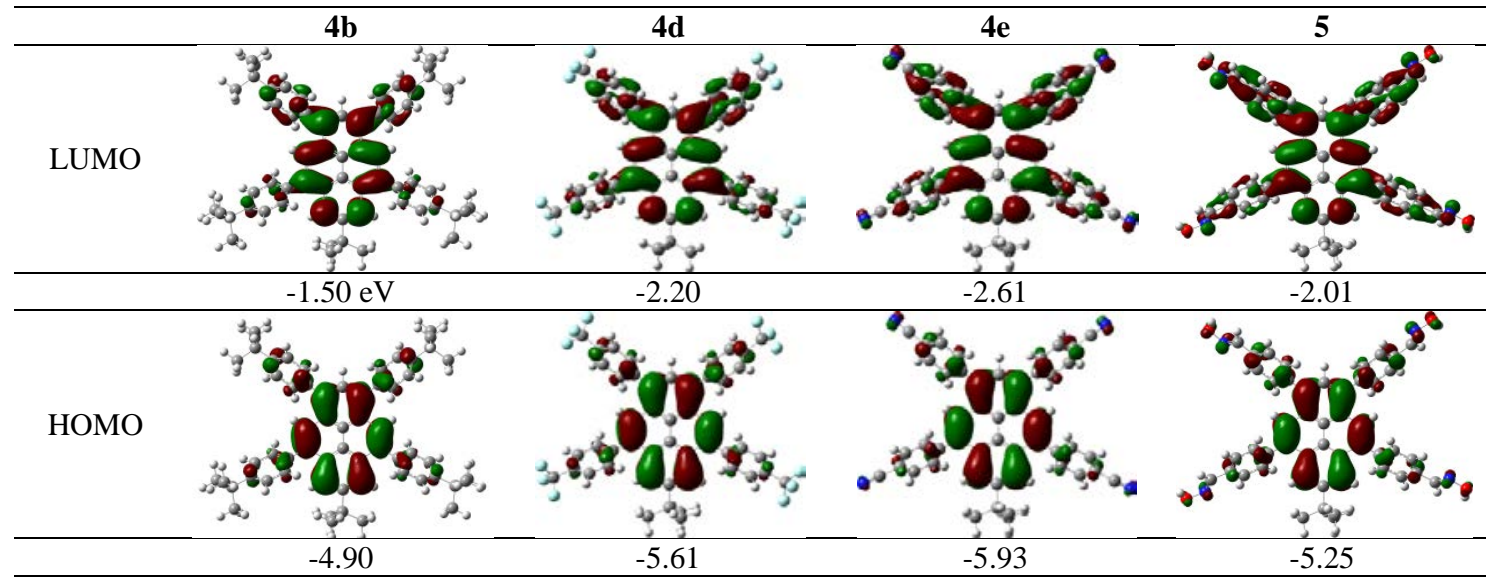

Fig. 6 Computed molecular orbital plots (B3LYP/6-31G*) of 4 and 5.

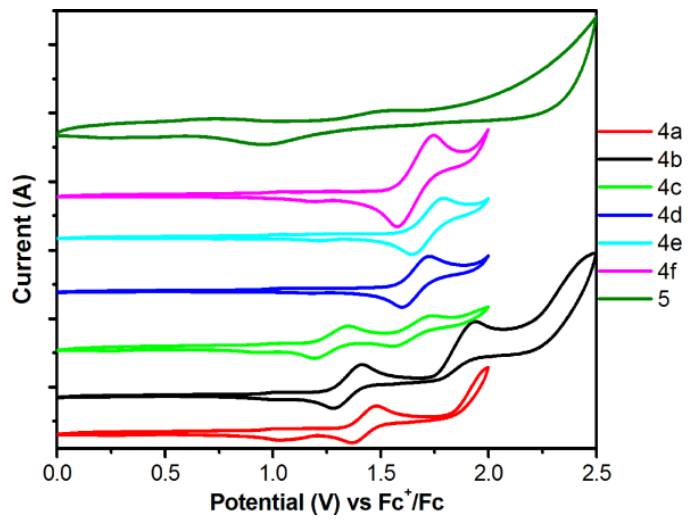

Fig. 5 Cyclic voltammograms recorded for compounds $\mathbf{4}$ and 5.

electronic structure and reversible oxidation characteristics. They are also clearly affected by the donator/acceptor groups of the 5 arylphenyl moieties at the 5,9- positions of the pyrene core in the current butterfly-shaped pyrenes. ${ }^{15}$ Accordingly, the HOMO and LUMO energy levels were estimated from the CVs and the UV-vis absorption and the data are summarized in Table 2. The HOMO energy levels increased from -5.36 to $-5.79 \mathrm{eV}$ in the 10 order: $\mathbf{4 e}>\mathbf{4 d}>\mathbf{4 f}>\mathbf{4 a}>\mathbf{4 b}=\mathbf{5}>\mathbf{4 c}$, and their LUMO energy levels were in the range -2.36 to $-2.96 \mathrm{eV}$. Based on the HOMO and LUMO energy levels, it can be proposed that these newly developed blue emitters $\mathbf{4}$ and $\mathbf{5}$ could be used as blue emitters in OLEDs.

15 To further understand the electronic properties of $\mathbf{4}, \mathbf{5}$ and $\mathbf{6}$, DFT calculations (B3LYP/6-31G* basis set) were carried out using Gaussian 03 for the geometry optimization. ${ }^{20}$ The optimized structures and orbital distributions of the HOMO and LUMO of these butterfly-shaped pyrenes are shown in both Fig. 6 and the ${ }_{20}$ supporting information. The dihedral angles between the arylphenyl and pyrene are in the range of $55-58^{\circ}$, which suggested that the different substituents equally contribute to the steric congestion in these system. The HOMO levels of $\mathbf{4 , 5}$ and $\mathbf{6}$ mainly involve contributions of $\pi$-orbitals from the pyrene core, 25 while the substituent aryl groups have limited contributions to these molecules. Similarly, the LUMO levels are also spread across the entire pyrene frameworks; however, acceptor groups with $\pi$-conjugation enlarged range from $-\mathrm{CF}_{3},-\mathrm{CN},-\mathrm{CHO}$ and $\mathrm{C}=\mathrm{N}-\mathrm{OH}$, the LUMOs located on entire molecules [I don't 30 understand this sentence - please re-write]. The HOMO-LUMO energy gaps were in the range of $3.21 \mathrm{eV}$ to $3.43 \mathrm{eV}$ in $\mathbf{4}$ and $\mathbf{5}$. Therefore, these theoretical calculations provided clear evidence that the red shift of the absorption and emission bands observed in compounds $\mathbf{4}$ and $\mathbf{5}$ are consistent with the experimental results. ${ }_{35}$ Without the tert-butyl group in $\mathbf{6}$, the energy gap resembles that of $\mathbf{4 a}$, but with a lower LUMO energy level.

\section{Conclusion}

In summary, in this study, a series of novel butterfly-shaped pyrene derivatives was successfully synthesized by the classical 40 Suzuki-Miyaura cross-coupling reaction. The introduction of several arylphenyl substituents located at the 1,3,5,9-positions of the pyrene influenced the FL emissions in solution and in the solid-state. The structure-property relationships of the donoracceptor interactions play a curial role in determining the thermal, ${ }_{45} \mathrm{UV}$-vis absorption, electrochemical behavior, etc. These pyrenes possess high solubility, high stability, highly blue emissions with quantum efficiency of up to $70 \%$, and long fluorescence lifetimes in solution. These excellent qualities make them very promising for applications in OLED devices.

\section{${ }_{50}$ Experimental}

\section{General}

All melting points (Yanagimoto MP-S S $_{1}$ are uncorrected. ${ }^{1} \mathrm{H}$ NMR spectra (300 MHz) were recorded on a Nippon Denshi JEOL FT-300 NMR 
spectrometer with $\mathrm{SiMe}_{4}$ as an internal reference: $J$-values are given in $\mathrm{Hz}$. IR spectra were measured for samples as $\mathrm{KBr}$ pellets in a Nippon Denshi JIR-AQ2OM spectrophotometer. UV-Vis spectra were measured using a Shimadzu UV-3150 UV-vis-NIR spectrophotometer. Fluorescence 5 spectroscopic studies of compounds in solution were performed in various organic solvents in a semimicro fluorescence cell (Hellma ${ }^{\circledR}, 104 \mathrm{~F}-\mathrm{QS}, 10$ $\times 4 \mathrm{~mm}, 1400 \mu \mathrm{L}$ ) with a Varian Cary Eclipse spectrophotometer, and Photoluminescence spectra of compounds in film were obtained using a FluroMax-2 (Jobin-Yvon-Spex) luminescence spectrometer. Fluorescence 10 quantum yields were measured (Hamamatsu Photonics K. K, Quantaurus-QY A10094) using integrated sphere absolute PL quantum yield measurement method. The luminescence lifetimes of the bufferfly-shaped compounds were obtained with Hamamatsu Photonics OB920 by using nanoLED excitation sources at 373 (ligand) or the 15 maximum $\lambda_{\mathrm{em}}$ of days \{I don't understand what this means 'of days'.\}. Thermogravimetric analysis (TGA) was carried out using a SEIKO EXSTAR 6000 TG/DTA 6200 unit under nitrogen atmosphere at a heating rate of $10{ }^{\circ} \mathrm{C} \mathrm{min}{ }^{-1}$. Differential scanning calorimetery (DSC) was performed using a Perkin-Elmer Diamond DSC Pyris instrument under a 20 nitrogen atmosphere at a heating rate of $10{ }^{\circ} \mathrm{C} \mathrm{min}^{-1}$. Mass Spectrometer at $75 \mathrm{eV}$ using a direct-inlet system [Not a proper sentence]. Elemental analyses were performed with a Yanaco MT-5 analyser. Cyclic voltammetry measurements were conducted using an ALS/H $\mathrm{CH}$ Instruments Electrochemical Analyzer 660B with a standard 25 three-electrode configuration. Typically, a three-electrode cell equipped with a Pt disk working electrode, a Pt wire counter electrode and an $\mathrm{Ag} / \mathrm{AgNO}_{3}$ (0.01 $\mathrm{M}$ in anhydrous acetonitrile) reference electrode was employed. The measurements were made in anhydrous dichloromethane (for oxidation) with $0.1 \mathrm{M} n$-tetrabutylammonium hexafluorophosphate as 30 the supporting electrolyte under an argon atmosphere at a scan rate of 100 $\mathrm{mV} / \mathrm{s}$. The potential of the $\mathrm{Ag} / \mathrm{AgNO}_{3}$ reference electrode was internally calibrated by using the ferrocene/ferrocenium redox couple $\left(\mathrm{Fc} / \mathrm{Fc}^{+}\right)$.

Materials: Unless otherwise stated, all other reagents used were 35 purchased from commercial sources and used without further purification. The preparation of 2-tert-butylpyrene (1) was described previously. ${ }^{21}$

Synthesis of 2-tert-butylpyrene (1). ${ }^{20} \mathrm{~A}$ mixture of pyrene (5 g (more s.f. needed), $24.2 \mathrm{mmol}$ ) and 2-chloro-2-methylpropane (2.62 g, $3.23 \mathrm{~mL}$ ) 40 was added in $40 \mathrm{~mL}$ of $\mathrm{CH}_{2} \mathrm{Cl}_{2}$ at $0{ }^{\circ} \mathrm{C}$ and stirred for $15 \mathrm{~min}$. Powdered anhydrous $\mathrm{AlCl}_{3}$ (3.62 g, $27.2 \mathrm{mmol}$ ) was slowly added to the stirred solution. The reaction mixture was continuously stirred for $3 \mathrm{~h}$ at room temperature and the reaction process was tracked by GC, and then poured into a large excess of ice/water. The reaction mixture was extracted with 45 dichloromethane $(2 \times 50 \mathrm{~mL})$. The combined organic extracts were washed by water and brine, dried with anhydrous $\mathrm{MgSO}_{4}$ and evaporated. The residue was crystallized from hexane to afford pure 2-tert-butylpyrene $\mathbf{1}$ (4.56 g, 71.4\%) as a gray powder. Recrystallization from hexane gave $\mathbf{1}$ as colorless prisms. M.p. $111.5-113.2^{\circ} \mathrm{C}$ (lit. ${ }^{20}$ M.p. 50 110-112 ${ }^{\circ} \mathrm{C}$ ). The ${ }^{1} \mathrm{H}$ NMR spectrum completely agreed with the reported values. ${ }^{1} \mathrm{H}$ NMR (300 MHz, $\mathrm{CDCl}_{3}$ ): $\delta=1.59$ (s, 9H, $t \mathrm{Bu}$ ), 8.18 (d, $J=$ $9.2 \mathrm{~Hz}, 2 \mathrm{H}$, pyrene- $H$ ), 8.30 (s, $2 \mathrm{H}$, pyrene- $H$ ), 8.37 (d, $J=9.2 \mathrm{~Hz}, 2 \mathrm{H}$, pyrene- $H$ ) and 8.47 (s, $1 \mathrm{H}$, pyrene- $H$ ) ppm.

55 Lewis acid-catalysed bromination of 2-tert-butylpyrene (1). A mixture of 2-tert-butylpyrene (0.512 g, 2 (more s.f. needed) mmol) and iron powder $(0.56 \mathrm{~g}, 10 \mathrm{mmol})$ was added while stirring for $15 \mathrm{~min}$ in
$\mathrm{CH}_{2} \mathrm{Cl}_{2}(10 \mathrm{~mL})$ at room temperature. Then, a solution of $\mathrm{Br}_{2}(0.63 \mathrm{~mL}$, $12.1 \mathrm{mmol})$ in $\mathrm{CH}_{2} \mathrm{Cl}_{2}(15 \mathrm{~mL})$ was slowly added dropwise with vigorous 60 stirring. After this addition, the reaction mixture was continuously stirred for $4 \mathrm{~h}$ at room temperature. The mixture was quenched with $\mathrm{Na}_{2} \mathrm{~S}_{2} \mathrm{O}_{3}$ $(10 \%)$ and extracted with dichloromethane $(2 \times 50 \mathrm{~mL})$. The combined organic extracts were washed with water and brine and then evaporated. The crude product exhibits a gray color. The crude product was insoluble 65 in general common organic solvents, such as benzene, hexane, methanol, etc. and only slightly dissolved in $\mathrm{CH}_{2} \mathrm{Cl}_{2}$ or $\mathrm{CHCl}_{3}$. Thus, the residue was dissolved in hot $\mathrm{CHCl}_{3}$ and filtered, then crystallizeation from $\mathrm{CHCl}_{3}$ to gave pure 7-tert-butyl-1,3,5,9-tetrabromopyrene 2 (978 $\mathrm{mg}, 84 \%$ ) as colourless prisms. M.p. $303.4-305.0^{\circ} \mathrm{C}$; IR: $v_{\max }(\mathrm{KBr}) / \mathrm{cm}^{-1}$ : 2962, 2365, 70 1579, 1523, 1461, 1425, 1392, 1363, 1267, 1195, 1132, 1027, 1012, 941, 877, 809, 655 and 474; ${ }^{1} \mathrm{H}$ NMR (300 MHz, $\mathrm{CDCl}_{3}$ ): $\delta=1.65$ (s, 9H, $t \mathrm{Bu}$ ), 8.47 (s, $1 \mathrm{H}$, pyrene- $H_{2}$ ), 8.71 (s, $2 \mathrm{H}$, pyrene- $H$ ) and 8.79 (s, $2 \mathrm{H}$, pyrene- $H$ ) $\mathrm{ppm}$. Due to the poor solubility, it was not further identified by ${ }^{13} \mathrm{C} N \mathrm{NMR}$ spectroscopy. FABMS: m/z: $573.62\left[\mathrm{M}^{+}\right] . \mathrm{C}_{20} \mathrm{H}_{14} \mathrm{Br}_{4}$ (573.78): calcd C 75 41.85, H 2.46; found: C 42.05, H 2.53.

Synthesis of 1,3,5,9-tetraaryl-7-tert-butylpyrenes (4). The series of butterfly-shaped compound $\mathbf{4 a - f}$ were synthesized from 1,3,5,9-tetrabromo-7-tert-butylpyrene $\mathbf{2}$ with the corresponding 80 arylboronic acid $\mathbf{3}$ by a Suzuki-Miyaura cross-coupling reaction in high yield.

Synthesis 7-tert-butyl-1,3,5,9-tetraphenylpyrene (4a). 7-tert-Butyl1,3,5,9-tetrabromopyrene 2 (200 mg, $0.35 \mathrm{mmoL}$ ), phenylboronic acid 3a 85 (245 mg, $2.11 \mathrm{mmol}$ ), $\mathrm{Pd}\left(\mathrm{PPh}_{3}\right)_{4}$ (70 mg, 0.06 \{more s.f needed\} mmol), and $\mathrm{K}_{2} \mathrm{CO}_{3}$ (0.5 \{more s.f needed\} g, $\left.3.6 \mathrm{mmol}\right)$ were mixed in a flask containing argon saturated toluene $(10 \mathrm{~mL})$ and ethanol $(4 \mathrm{~mL})$. The reaction mixture was stirred at $90^{\circ} \mathrm{C}$ for $24 \mathrm{~h}$. After it was cooled to room temperature, the reaction mixture was extracted with dichloromethane (3 $90 \times 50 \mathrm{~mL}$ ), and the organic layer was washed with $\mathrm{H}_{2} \mathrm{O}$ and brine, then dried with anhydrous $\mathrm{MgSO}_{4}$ and evaporated. The crude product was purified by column chromatography using dichloromethane as eluent to afford a deep yellow solid. Recrystallization from a mixture of $\mathrm{CH}_{2} \mathrm{Cl}_{2}-$ methanol (2:1) gave $\mathbf{4 a}(128 \mathrm{mg}, 65 \%)$ as colourless needles. M.p. $335^{\circ} \mathrm{C}$. 95 IR: $v_{\max }(\mathrm{KBr}) / \mathrm{cm}^{-1}$ : 3422.5, 2961.0, 2366.6, 1593.2, 1496.6, 1363.8, 1252.8, 1177.6, 1070.3, 894.7, 762.3, 701.3, 626.1 and 483.1. ${ }^{1} \mathrm{H}$ NMR (400 MHz, $\left.\mathrm{CDCl}_{3}\right): \delta=1.36$ (s, 9H, $\left.t \mathrm{Bu}\right), 7.40-7.54(\mathrm{~m}, 12 \mathrm{H}, \mathrm{Ar}-H$ ), 7.63-7.70 (m, 8H, Ar-H), 7.98 (s, $1 \mathrm{H}$, pyrene- $H$ ), 8.16 (s, 2H, pyrene- $H$ ) and 8.29 (s, $2 \mathrm{H}$, pyrene- $H$ ) ppm. ${ }^{13} \mathrm{C}$ NMR $\left(100 \mathrm{MHz}, \mathrm{CDCl}_{3}\right): \delta=148.6$, 100 141.4, 141.1, 139.8, 137.2, 130.6, 130.5, 130.1, 129.7, 128.4, 128.3, 127.4, 127.3, 127.2, 125.5, 124.5, 124.1, 121.4, 35.4 and 31.6 ppm. FABMS: m/z: $562.28\left(\mathrm{M}^{+}\right) . \mathrm{C}_{44} \mathrm{H}_{34}$ (562.74): calcd C 93.62, H 5.38; found: C 93.25., H 5.25 .

105 7-tert-Butyl-1,3,5,9-tetrakis(4-tert-butylphenyl)pyrene (4b): Colourless prisms $\left(\mathrm{CH}_{2} \mathrm{Cl}_{2}\right.$ :methanol, 2:1) (132 mg, 48\%). M.p. $332{ }^{\circ} \mathrm{C}$. IR: $v_{\max }$ $(\mathrm{KBr}) / \mathrm{cm}^{-1}:$ 2964, 1596, 1510, 1460, 1396, 1363, 1270, 1109, 1023, 901, 833, 572 and 482. ${ }^{1} \mathrm{H}$ NMR (400 MHz, $\mathrm{CDCl}_{3}$ ): $\delta=1.39$ (s, 9H, pyrene-tBu), 1.42 (s, 18H, phenyl-tBu), $\delta_{\mathrm{H}}: 1.44$ (s, 18H, pyrene-tBu), 1107.54 (d, $J=8.4 \mathrm{~Hz}, 4 \mathrm{H}, \mathrm{Ar}-H$ ), 7.57 (d, $J=8.8 \mathrm{~Hz}, 4 \mathrm{H}, \mathrm{Ar}-H$ ), 7.62 (d, $J$ $=7.6 \mathrm{~Hz}, 4 \mathrm{H}, \operatorname{Ar}-H), 7.63(\mathrm{~d}, J=7.6 \mathrm{~Hz}, 4 \mathrm{H}, \operatorname{Ar}-H), 7.98(\mathrm{~s}, 1 \mathrm{H}$, pyrene- $H$ ), 8.26 (s, $2 \mathrm{H}$, pyrene- $H$ ) and 8.33 (s, $2 \mathrm{H}$, pyrene- $H$ ) ppm. ${ }^{13} \mathrm{C}$ NMR (100 MHz, $\left.\mathrm{CDCl}_{3}\right): \delta=150.2,149.9,148.3,139.3,138.5,138.2$, 137.0, 130.6, 130.3, 130.0, 129.9, 128.9, 127.2, 125.7, 125.3, 125.2, 124.4, 115 124.2, 121.2, 35.4, 34.7, 34.6, 31.7 and 31.4 ppm. FABMS: m/z: 786.58 
$\left[\mathrm{M}^{+}\right] . \mathrm{C}_{60} \mathrm{H}_{66}$ (786.52): C 91.55, H 8.45; found: C 91.25, H 8.55.

7-tert-Butyl-1,3,5,9-tetrakis(4-methoxyphenyl)pyrene (4c). Yellow prisms $\left(\mathrm{CH}_{2} \mathrm{Cl}_{2}\right.$-methanol, 2:1) (154 mg, 65\%). M.p. $330{ }^{\circ} \mathrm{C}$. IR: $v_{\max }$ $5(\mathrm{KBr}) / \mathrm{cm}^{-1}$ : 3437, 2957, 1610, 1507, 1457, 1285, 1246, 1174, 1106, 1038, 830, 583 and 540. ${ }^{1} \mathrm{H}$ NMR (400 MHz, $\mathrm{CDCl}_{3}$ ): $\delta=1.38$ (s, 9H, $t \mathrm{Bu}$ ), 3.90 (s, 6H, OMe), 3.92 (s, 6H, OMe), 7.06 (d, $J=8.8 \mathrm{~Hz}, 4 \mathrm{H}, \mathrm{Ar}-H$ ), 7.07 (d, $J=8.8 \mathrm{~Hz}, 4 \mathrm{H}, \mathrm{Ar}-H$ ), 7.56 (d, $J=8.6 \mathrm{~Hz}, 4 \mathrm{H}, \mathrm{Ar}-H$ ), 7.60 (d, $J$ $=8.8 \mathrm{~Hz}, 4 \mathrm{H}, \mathrm{Ar}-H), 7.92(\mathrm{~s}, 1 \mathrm{H}$, pyrene- $H), 8.12(\mathrm{~s}, 2 \mathrm{H}$, pyrene- $H)$ and 108.30 (s, 2H, pyrene- $H$ ) ppm; ${ }^{13} \mathrm{C}$ NMR $\left(100 \mathrm{MHz}, \mathrm{CDCl}_{3}\right) \delta=159.0$, 158.9, 148.5, 139.1, 136.7, 133.9, 133.7, 131.7, 131.2, 130.8, 129.7, 127.3, 125.6, 121.2, 113.9, 113.8, 55.4 and 31.7 ppm; FABMS: $\mathrm{m} / \mathrm{z}: 682.19$ $\left[\mathrm{M}^{+}\right] . \mathrm{C}_{48} \mathrm{H}_{42} \mathrm{O}_{4}$ (682.31): calcd C 84.43, H 6.20; found: C 84.01, H 5.93.

15 7-tert-Butyl-tetrakis-1,3,5,9-(4-trifluorophenyl)pyrene (4d). Colourless prisms $\left(\mathrm{CH}_{2} \mathrm{Cl}_{2}\right.$-methanol, 2:1) (183 mg, 63\%). M.p. $258{ }^{\circ} \mathrm{C}$. IR: $v_{\max }$ $(\mathrm{KBr}) / \mathrm{cm}^{-1}:$ 2961, 1614, 1403, 1324, 1256, 1167, 1123, 1067, 1020, 852, 623 and 436. ${ }^{1} \mathrm{H}$ NMR (400 MHz, $\mathrm{CDCl}_{3}$ ): $\delta=1.38$ (s, 9H, $t \mathrm{Bu}$ ), 7.73 7.84 (m, $16 \mathrm{H}, \mathrm{Ar}-H$ ), 7.94 (s, $1 \mathrm{H}$, pyrene- $H$ ), 8.05 (s, $2 \mathrm{H}$, pyrene-H) 20 and 8.25 (s, $2 \mathrm{H}$, pyrene- $H$ ) ppm; ${ }^{13} \mathrm{C}$ NMR $\left(100 \mathrm{MHz}, \mathrm{CDCl}_{3}\right): \delta=149.7$, 144.4, 144.1, 139.3, 136.2, 130.9, 130.8, 130.3, 130.0, 129.3, 127.4, 125.6, 125.54, 125.51, 125.4, 125.3, 125.2, 125.16, 124.7, 123.9, 122.8, 121.8, 35.5 and 31.6 ppm. FABMS: $\mathrm{m} / \mathrm{z}$ : $834.29\left[\mathrm{M}^{+}\right] . \mathrm{C}_{48} \mathrm{H}_{30} \mathrm{~F}_{12}$ (834.73): calcd C 69.07, H 3.62; found: C 68.97, H 3.83.

25

7-tert-Butyl-tetrakis-1,3,5,9-(4-cyanophenyl)pyrene (4e). Colourless prisms $\left(\mathrm{CH}_{2} \mathrm{Cl}_{2}\right.$-methanol, 2:1) (144 mg, 62\%). M.p. $378{ }^{\circ} \mathrm{C}$. IR: $v_{\max }$ $(\mathrm{KBr}) / \mathrm{cm}^{-1}:$ 2954, 2230, 1683, 1604, 1504, 1480, 1256, 1178, 1109, 995, 898, 837 and 562. ${ }^{1} \mathrm{H}$ NMR (400 MHz, $\mathrm{CDCl}_{3}$ ): $\delta=1.37$ (s, 9H, $t \mathrm{Bu}$ ), 307.73 (d, $J=8.2 \mathrm{~Hz}, 4 \mathrm{H}, \mathrm{Ar}-H$ ), 7.78 (d, $J=8.2 \mathrm{~Hz}, 4 \mathrm{H}, \mathrm{Ar}-H$ ), 7.87 (d, $J$ $=8.2 \mathrm{~Hz}, 4 \mathrm{H}, \operatorname{Ar}-H), 7.88(\mathrm{~d}, \mathrm{~J}=8.1 \mathrm{~Hz}, 4 \mathrm{H}, \operatorname{Ar}-H), 7.92(\mathrm{~s}, 1 \mathrm{H}$, pyrene- $H$ ), 7.98 (s, $2 \mathrm{H}$, pyrene- $H$ ) and 8.21 (s, $2 \mathrm{H}$, pyrene- $H$ ) ppm. ${ }^{13} \mathrm{C}$ NMR (100 MHz, $\left.\mathrm{CDCl}_{3}\right): \delta=147.5,142.7,142.4,136.8,133.4,129.9$, 128.5, 128.1, 127.1, 126.4, 124.8, 122.4, 122.2, 121.2, 119.4, 116.0, 35 115.96, 109.4, 109.2, 33.0 and 29.0 ppm. FABMS: m/z: $662.31\left[\mathrm{M}^{+}\right]$. $\mathrm{C}_{48} \mathrm{H}_{30} \mathrm{~N}_{4}$ (662.78): calcd C 86.98, H 4.56; found: C 86.68, H 4.88.

7-tert-Butyl-1,3,5,9-tetrakis(4-formylphenyl)pyrene (4f). Yellow prisms $\left(\mathrm{CH}_{2} \mathrm{Cl}_{2}\right.$-methanol, 2:1) (168 mg, 72\%). M.p. $302{ }^{\circ} \mathrm{C}$. IR: $v_{\max }$ $40(\mathrm{KBr}) / \mathrm{cm}^{-1}$ : 3444, 2957, 1703, 1607, 1564, 1385, 1313, 1209, 1167, 819 and 490. H NMR (400 MHz, $\mathrm{CDCl}_{3}$ ): $\delta=1.37$ (s, $\left.9 \mathrm{H}, t \mathrm{Bu}\right), 7.81$ (d, $J=$ $8.1 \mathrm{~Hz}, 4 \mathrm{H}, \mathrm{Ar}-H$ ), 7.87 (d, $J=8.1 \mathrm{~Hz}, 4 \mathrm{H}, \mathrm{Ar}-H$ ), 8.00 (s, $1 \mathrm{H}$, pyrene- $H$ ), 8.07-8.09 (m, 8H, Ar- $H, 2 \mathrm{H}$, pyrene-H), 8.28 (s, 2H, pyrene- $H$ ), 10.14 (s, $2 \mathrm{H}, \mathrm{CHO})$ and 10.16 (s, 2H, CHO) ppm. ${ }^{13} \mathrm{C} \mathrm{NMR}\left(100 \mathrm{MHz}, \mathrm{CDCl}_{3}\right): \delta$ $45=191.82,191.77,149.8,147.1,146.8,139.6,136.5,135.7,135.5,131.2$, 130.7, 130.0, 129.9, 129.0, 128.9, 127.5, 125.3, 124.8, 123.9, 122.0, 35.5 and 31.6 ppm. FABMS: $m / z$ : $674.28\left[\mathrm{M}^{+}\right] . \mathrm{C}_{48} \mathrm{H}_{34} \mathrm{O}_{4}$ (674.78): calcd C 85.44, H 5.08; found: C 85.34, H 5.35.

50 Synthesis of 7-tert-butyl-1,3,5,9-tetrakis(4-hydroxyiminophenyl)pyrene (5). A mixture of 7-tert-butyl-1,3,5,9-tetrakis(4-formylphenyl)pyrene $\quad$ 4f $(30 \mathrm{mg}, \quad 0.045$ $\mathrm{mmoL}$ ), hydroxylamine hydrochloride (60 $\mathrm{mg}, 0.86 \mathrm{mmol}$ ), sodium hydroxyde (30 mg, $0.75 \mathrm{mmoL}$ ) and $10 \mathrm{~mL}$ ethanol were refluxed for 12 $55 \mathrm{~h}$, and then cooled to room temperature. The solvent was removed in vacuo to leave the residue, which was washed with water and recrystallized from acetone to give 5 (23 $\mathrm{mg}, 70 \%)$ as a yellow solid. M.p. $214{ }^{\circ} \mathrm{C}$. IR: $v_{\max }(\mathrm{KBr}) / \mathrm{cm}^{-1}: 33465,2974,1756,1630,1371,1249,1218$,
1072, 1009, 974, 943, 836, 730, 607, 568, 524 and 466. ${ }^{1} \mathrm{H}$ NMR (400 $60 \mathrm{MHz}_{\mathrm{CDCl}}$ ): $\delta=1.29$ (s, 9H, $\mathrm{BBu}$ ), 2.22 (s, $4 \mathrm{H}, \mathrm{OH}$ ), 7.34 (d, $J=8.0 \mathrm{~Hz}$, 4H, Ar-H), 7.45 (d, $J=8.0 \mathrm{~Hz}, 4 \mathrm{H}, \mathrm{Ar}-H$ ), 7.53 (d, $J=8.0 \mathrm{~Hz}, 4 \mathrm{H}, \mathrm{Ar}-H$ ), 7.62, (s, 2H, pyrene- $H$ ), 7.66 (d, $J=8.0 \mathrm{~Hz}, 4 \mathrm{H}, \operatorname{Ar}-H$ ), 7.67 (s, $2 \mathrm{H}$, $-\mathrm{CH}=\mathrm{N}-H$ ), 8.05 (s, 2H, $-\mathrm{CH}=\mathrm{N}-H), 8.14$ (d, $J=9.2 \mathrm{~Hz}, 2 \mathrm{H}$, pyrene- $H$ )) and 8.24 (s, $2 \mathrm{H}$, pyrene- $H$ ) ppm; ${ }^{13} \mathrm{C}$ NMR $\left(100 \mathrm{MHz}, \mathrm{CDCl}_{3}\right): \delta=$ 65 115.02, 150.0, 149.8, 143.3, 142.9, 140.7, 138.1, 133.9, 133.6, 131.9, 131.8, 131.5, 131.3, 130.0, 129.8, 128.3, 128.0, 127.9, 126.4, 125.7, 125.4, 122.7, 36.4 and 32.1 ppm. FABMS: $m / z$ : $734.52\left[\mathrm{M}^{+}\right]$. calcd $\mathrm{C}_{48} \mathrm{H}_{38} \mathrm{~N}_{4} \mathrm{O}_{4}$ (734.84): C 78.45, H 5.21; found: C 78.20, H 5.25.

70 Synthesis of 1,3,5,9-tetrakisphenylpyrene (6). A mixture of 7-tert-butyl-1,3,5,9-tetrakisphenylpyrene 4a $(50 \mathrm{mg}, 0.09$ \{more s.f needed mmoL), Nafion- $\mathrm{H}(50 \mathrm{mg}$ ), and $2 \mathrm{~mL} o$-xylene were refluxed for $24 \mathrm{~h}$, and then cooled to room temperature. The solid was removed in vacuo and the mother solution collected. The crude product was purified 75 by column chromatography using dichloromethane-hexane (1:1) as eluent to afford a yellow solid. Recrystallization from a mixture of $\mathrm{CH}_{2} \mathrm{Cl}_{2}-$ ethanol (2:1) gave 6 (23 mg, 51\%) as light yellow prisms. M.p. $244{ }^{\circ} \mathrm{C}$. IR: $v_{\max }(\mathrm{KBr}) / \mathrm{cm}^{-1}: 3058,3032,1600,1486,1442,1071,1034,893,790$, 759, 740, 700, 620 and 475. ${ }^{1} \mathrm{H}$ NMR (400 MHz, $\left.\mathrm{CDCl}_{3}\right): \delta=7.42-7.45$ 80 (m, 4H, Ar-H), 7.49-7.53 (m, 8H, Ar- $H$ ), 7.59-7.61 (m, 4H, Ar-H), 7.66-7.68 (m, 4H, Ar-H), 7.85-7.89, (m, $1 \mathrm{H}$, pyrene- $H$ ), 8.00 (s, $1 \mathrm{H}$, pyrene- $H$ ), 8.17 (s, 2H, pyrene- $H$ ) and 8.14 (d, $J=8 \mathrm{~Hz}, 2 \mathrm{H}$, pyrene- $H$ )) ppm; ${ }^{13} \mathrm{C}$ NMR (100 MHz, $\mathrm{CDCl}_{3}$ ): $\delta=141.2,141.0,139.6,137.4,130.7$, 130.6, 130.1, 130.0, 128.4, 128.3, 127.4, 127.39, 127.2, 125.7, 125.5 and 85124.1 ppm. FABMS: $m / z$ : $506.12\left(\mathrm{M}^{+}\right) . \mathrm{C}_{40} \mathrm{H}_{26}$ (506.20): calcd C $94.83, \mathrm{H}$ 5.17; found: C 94.77, H 5.29.

\section{Acknowledgements}

This work was performed under the Cooperative Research Program of "Network Joint Research Center for Materials and 90 Devices (Institute for Materials Chemistry and Engineering, Kyushu University)”. We would like to thank the OTEC at Saga University and the International Collaborative Project Fund of Guizhou province at Guizhou University for financial support. We also would like to thank the EPSRC and The Royal Society 95 for financial support (travel grants to C.R.).

\section{Notes}

${ }^{a}$ Department of Applied Chemistry, Faculty of Science and Engineering, Saga University, Honjo-machi 1, Saga 840-8502 Japan, E-mail: yamatot@cc.saga-u.ac.jp

$100{ }^{b}$ Emergent Molecular Function Research Group, RIKEN Center for Emergent Matter Science (CEMS), Wako, Saitama 351-0198, Japan, E-mail: jian-yong.hu@riken.jp

${ }^{c}$ Department of Chemistry, The University of Hull, Cottingham Road, Hull, Yorkshire, HU6 7RX, UK.

${ }_{105}{ }^{d}$ Chemistry Department, Loughborough University, Loughborough, LE11 3TU, UK.

†Electronic Supplementary Information (ESI) available: ${ }^{1} \mathrm{H} /{ }^{13} \mathrm{C}$ NMR spectra of $\mathbf{4 a - f ,} \mathbf{5}$ and $\mathbf{6}$, the effect of different solvents on the fluorescence emission spectra of $\mathbf{4}$ and $\mathbf{5}$, etc. See 110 DOI: $10.1039 / \mathrm{b} 000000 \mathrm{x} /$

\section{References}

1 (a) P. Tyagi, A. Venkateswararao and K. R. J. Thomas, J. Org. Chem., 2011, 76, 4571-4581; (b) L. Schmidt-Mende, A. Fechtenkötter, K. 
Müllen, E. Moons, R. H. Friend and J. D. MacKenzie, Science, 2001, 293, 1119-1122.

2 (a) X.-L. Feng, W. Pisula and K. Müllen, Pure Appl. Chem., 2009, 81, 2203-2224; (b) H. Klauk, D. J. Gundlach, J. A. Nichols and T. N. Jackson, IEEE T ELECTRON DEV., 1999, 46, 1258-1263; (c) S.-L. Suraru, U. Zschieschang, H. Klauk and F. Würthner, Chem. Commum., 2011, 47, 11504-11506.

3 (a) M. A. Baldo, D. F. O’Brien, Y. You, A. Shoustikov, S. Sibley, M. E. Thompson and S. R. Forrest, Nature, 1998, 395, 151-154; (b) C.-T. Chen, Chem. Mater., 2004, 16, 4389-4400.

4 (a) T. M. Figueira-Duarte and K. Müllen, Chem. Rev., 2011, 111, 7260-7314; (b) J.-Y. Hu and T. Yamato, Organic Light Emitting Diode - Material, Process and Devices. 2011, 21-60; (c) J.-Y. Hu, Y.-J. Pu, G. Nakata, S. Kawata, H. Sasabe and J. Kido, Chem. Commun., 2012, 48, 8434-8436.

5 (a) Y.-L. Fogel, M. Kastler, Z.-H. Wang, D. Andrienko, G. J. Bodwell and K. Müllen, J. Am. Chem. Soc., 2007, 129, 1174311749; (b) K. Mochida, K. Kawasumi, Y. Segawa and K. Itami, J. Am. Chem. Soc., 2011, 133, 10716-10719; (c) B.-X. Gao, M. Wang,

20 Y.-X. Cheng, L.-X. Wang, X.-B. Jing and F.-S. Wang, J. Am. Chem. Soc., 2008, 130, 8297-8306.

6 (a) X.-L. Ni, S. Wang, X. Zeng, Z. Tao and T. Yamato, Org. Lett., 2011, 13, 552-555; (b) X.-L Ni, X. Zeng, C. Redshaw and T. Yamato, J. Org. Chem., 2011, 76, 5696-5702; (c) X.-L Ni, X. Zeng, C. Redshaw and T. Yamato, Tetrahedron, 2011, 67, 3248-3253.

7 I. B. Berlman, J. Phys. Chem., 1970, 74, 3085-3093.

8 P. Sonar, M. S. Soh, Y. H. Cheng, J. T. Henssler and A. Sellinger, Org. Lett., 2010, 15, 3292-3295.

9 W. Sotoyama, H. Sato, M. Kinoshita, T. Takahashi, A. Matsuura, J.

30 Kodama, N. Sawatari and H. Inoue, SID Symposium Digest of Technical Papers, 2003, 34, 1294-1297.

10 (a) J.-Y. Hu, M. Era, M. R. J. Elsegood and T. Yamato, Eur. J. Org. Chem., 2010, 72-79; (b) J.-Y. Hu, X.-L. Ni, X. Feng, M. Era, M. R. J. Elsegood, S. J. Teat and T. Yamato, Org. Biomol. Chem., 2012, 10,

35 2255-2262; (c) X. Feng, J.-Y. Hu, L. Yi, N. Seto, Z. Tao, C. Redshaw, M. R. J. Elsegood and T. Yamato, Chem.-Asian J., 2012, 7, 2854-2863.

11 X. Feng, J.-Y. Hu, F. Iwanaga, N. Seto, C. Redshaw, M. R. J. Elsegood and T. Yamato, Org. Lett., 2013, 15, 1318-1321.

4012 M. Tasashi and T. Yamato, J. Org. Chem., 1983, 48, 1461-1468.

13 (a) T. Yamato, C. Hideshima, A. Miyazawa, M. Tashiro, G. K. S. Prakash and G. A. Olah, Catal. Lett., 1990, 6, 345-348; (b) G. A. Olah, G. K. S. Prakash, P. S. Iyer, M. Tashiro, and T. Yamato, J. Org. Chem., 1987, 52, 1881-1884; (c) T. Yamato, C. Hideshima, M.

45 Tashiro, G. K. S. Prakash and G.A. Olah, J. Org. Chem., 1991, 56, 6248-6250; (d) T. Yamato, J. Synth. Org. Chem. Jpn., 1995, 53, 487-499; (e) T. Yamato and J. Hu, J. Chem. Res., 2006, 762-765.

14 C.-J. Chen, H.-J. Yen, W.-C. Chen and G.-S. Liou, J. Polym. Sci., Part A: Polym. Chem., 2011, 49, 3709-3718.

5015 A. G. Crawford, A. D. Dwyer, Z.-Q. Liu, A. Steffen, A. Beeby, L.-O. Pålsson, D. L. Tozer and T. B. Marder, J. Am. Chem. Soc., 2011, 133 13349-13362.

16 J. N. Moorthy, P. Natarajan, P. Venkatakrishnan, D.-F. Huang and T. J. Chow, Org. Lett., 2007, 9, 5215-5218.

5517 E. M. S. Castanheira, M. S. D. Carvalho, D. J. G. Soares, P. J. G. Coutinho, R. C. Calhelha and M-J. R. P. Queiroz, J. Fluorescence, 2011, 21, 911-922.

18 (a) F. Han, L. Chi, W. Wu, X. Liang, M. Fu, J .Zhao, J. Photochem. Photobio. A: Chem., 2008, 196, 10-23. (b) G.-J. Zhao, J.-Y. Liu, L.-C.

60 Zhou, K.-L. Han, J. Phys. Chem. B, 2007, 111, 8940-8945.

19 J. C. Sciano, Handbook of Organic Photochemistry; CRC Press: Boca Raton, FL, 1989.

20 M. J. Frisch, G. W. Trucks, H. B. Schlegel, G. E. Scuseria, M. A. Robb, J. R. Cheeseman, J. A., Jr. Montgomery, T. Vreven, K. N.

65 Kudin, J. C. Burant, J. M. Millam, S. S. Iyengar, J. Tomasi, V. Barone, B. Mennucci, M. Cossi, G. Scalmani, N. Rega, G. A. Petersson, H. Nakatsuji, M. Hada, M. Ehara, K. Toyota, R. Fukuda, J. Hasegawa, M. Ishida, T. Nakajima, Y. Honda, O. Kitao, H. Nakai, M. Klene, X. Li, J. E. Knox, H. P. Hratchian, J. B. Cross, V. Bakken, C.
Austin, R. Cammi, C. Pomelli, J. W. Ochterski, P. Y. Ayala, K. Morokuma, G. A. Voth, P. Salvador, J. J. Dannenberg, V. G. Zakrzewski, S. Dapprich, A. D. Daniels, M. C. Strain, O. Farkas, D. K. Malick, A. D. Rabuck, K. Raghavachari, J. B. Foresman, J. V. 75 Ortiz, Cui, Q.; Baboul, A. G.; Clifford, S.; Cioslowski, J.; Stefanov, B. B.; G. Liu, A. Liashenko, P. Piskorz, I. Komaromi, R. L. Martin, D. J. Fox, T. Keith, M. A. Al-Laham, C. Y. Peng, A. Nanayakkara, M. Challacombe, P. M. W. Gill, B. Johnson, W. Chen, M. W. Wong, C. Gonzalez and J. A. Pople, Gaussian 03, revision C.02, Gaussian, Inc., Wallingford CT, 2004.

21 Y. Miura, E. Yamano, A. Tanaka and J. Yamauchi, J. Org. Chem., 1994, 59, 3294-3300. 